\title{
Intra- and interpopulational genetic variation in juvenile populations of Quercus robur $L$ and Quercus petraea Liebl
}

\author{
G Müller-Starck $1,2^{\star}$, S Herzog 1 , HH Hattemer 1 \\ ${ }^{1}$ Institut für Forstgenetik und Forstpflanzenzüchtung der Universität Göttingen, \\ 3400 Göttingen-Weende, Germany; \\ 2 Eidgenöss, Forschungsanstalt für Wald, Schnee und Landschaft, \\ Zürcherstrasse 111, 8903 Birmensdort, Switzerland
}

\begin{abstract}
Summary - In each of 5 2-year-old populations of Quercus robur and $Q$ petraea (single and multipopulation samples), genetic variation was quantified with respect to 13 polymorphic enzyme coding gene loci. Genetic control and inheritance of isoenzymes was verified beforehand by means of analyses of full-sib families. The observed average heterozygosities were $21.3 \% Q$ robur and $21.9 \%$ for $Q$ petraea (conditional heterozygosities of 56.6 and 56.7 respectively). The mean number of alleles per locus is 3.2 for $Q$ robur and 3.1 for $Q$ petraea. The relatively small genetic diversities indicate minor polymorphisms. The genetic distances between pairs of samples indicate remarkable differences between populations. Most of the single population samples could be proven to share a smaller proportion of the entire gene pool than each of the multipopulation samples. There is a strong genetic similarity between $Q$ robur and $Q$ petraea in terms of common alleles. It is concluded that, more than in other species, large genetic variation must be incorporated into oak population in order to maintain the ability of these species to adapt to heterogeneous environments.
\end{abstract}

Quercus robur / Q petraea / alloenzymes / heterozygosity / diversity / genetic distahce / genetic differentiation

Résumé - Variabilité génétique intra- et interpopulation dans de jeunes populations de Quercus robur $L$ et de Quercus petraea Liebl. La variablité générique a été estimée dans 5 populations de Quercus robur et 5 populations de $\mathrm{Q}$ petraea à partir de 13 loci polymorphes contrôlant l'expression d'enzymes. L'hérédité mendélienne des isozymes a été au préalable vérifiée par l'étude

\footnotetext{
* Send all correspondence to address 2 .
} 
de ségrégation dans les croisements contrôlés. Les valeurs moyennes de l'hétérozygotie observée sont de $21,3 \%$ chez $Q$ robur et $21,9 \%$ chez $Q$ petraea. Les mêmes valeurs pour les hétérozygoties conditionnelles sont de $56,6 \%$ et $56,7 \%$. Le nombre moyen d'allèles est de 3,2 pour $\mathrm{Q}$ robur et 3,1 pour $\mathrm{Q}$ petraea. Les diversités génétiques sont relativement peu élevées. Les distances génétiques entre populations indiquent de très fortes différences entre elles. Les populations prises individuellement partagent une partie plus faible de l'ensemble du pool génétique que les populations regroupées entre elles. Les allèles communs indiquent une très forte similarité entre $Q$ robur et $Q$ petraea. En conclusion, il est recommandé de conserver une variabilité génétique élevée dans les chênaies de manière à maintenir leur aptitude à s'adapter à des milieux hétérogènes.

Quercus robur / Quercus petraea / allozymes / hétérozygotie / diversité / distance génétique / différenciation génétique

\section{INTRODUCTION}

Quercus robur $\mathrm{L}$ (penduculate oak) and Quercus petraea Liebl (sessile oak) belong to the major deciduous tree species in Germany. Like Fagus sylvatica L, oaks are carrier tree species of complex forest ecosystems which range from the lowlands to the submountainous or even the moutainous regions. Oaks are extremely long-lived species with forest rotation cycles of 200 or more years. Oaks are exposed to more heterogeneous environments over time than any other predominant tree species. In the study of genetic variation and its implications on the ability of tree populations to survive in complex environmental situations, oaks may function well as model organisms.

The objective of the present study was to proceed in the description of the genetic variation in oak populations and thus in the characterization of the natural variability of forest ecosystems. Data on patterns of genetic variation will contribute to a better understanding of principles of adaptation and survival of oaks and are needed as criteria for the choice of reproductive material, for silvicultural treatment as well as for declaration and conservation of genetic resources.

\section{MATERIALS AND METHODS}

\section{Samples}

For each species, 5 populations were grown from commercially utilized seed lots (see table I) which are commonly used for artificial regeneration in Germany. Two categories of commercial reproductive material are involved: 1 ) mixtures of seed lots which originate from harvest in different stands which all together belong to the same region of provenance ('multipopulation samples'); and 2) material which originates from single oak stands which cover areas of $50-100$ ha. All stands are supposed to be predominantly indigenous. A total of 1605 individuals were genotyped at the age of $2 \mathrm{yr}$. For location of the origin of the studied samples, see Müller-Starck and Ziehe (1991).

\section{Genotyping}

Genetic control and inheritance of isoenzymes was verified beforehand by utilizing full-sib families and their parents of $Q$ robur and $Q$ petraea (Müller-Strack and Hattemer, 1990). For extraction of bud and leaf tissues, enzymes were separated by starch-gel electrophoresis and isoelectric focusing mean of genotyping see MüllerStarck and Ziehe (1991). Enzyme systems with environmentally dependent expression of isoenzymes, such as acid phosphatases or esterases, were excluded from further studies. Ten en- 
Table I. List of the studied population samples.

\begin{tabular}{|c|c|c|c|c|}
\hline \multicolumn{2}{|c|}{ Sample } & \multirow[t]{2}{*}{ Species } & \multirow{2}{*}{$\begin{array}{c}\text { Region of } \\
\text { provenance }\end{array}$} & \multirow{2}{*}{$\begin{array}{l}\text { Locations, forest districts, } \\
\text { or regional designations }\end{array}$} \\
\hline No & Size & & & \\
\hline $1^{b}$ & 208 & Q robur & 81703 & Peine/Ülzen/Wolfsburg \\
\hline $2^{b}$ & 204 & Q robur & 81704 & Walkenried/Lappwald/Hofgeismar \\
\hline $3^{\circ}$ & 204 & Q robur & 81706 & Südbaden \\
\hline 4 & 120 & Q robur & 81705 & Gelnhausen \\
\hline 5 & 96 & Q robur & 81705 & Nidda \\
\hline $6^{b}$ & 216 & Qpetraea & 81807 & Alfeld/Hildesheim/Salzgitter \\
\hline $7 \mathrm{~b}$ & 72 & Q petraea & 81804 & Peine/Nienburg \\
\hline 8 & 228 & $Q$ petraea & 81807 & Rotenburg \\
\hline 9 & 174 & Qpetraea & 81811 & Biebergemünd \\
\hline 10 & 84 & $Q$ petraea & 81812 & Gräfendorf \\
\hline
\end{tabular}

a Anonymous (1972). ${ }^{\circ}$ Multi-population sample.

zyme systems were studied (abbreviations and EC No / in brackets): Aminopeptidase (AP, 3.4.11.1, leucine-and alanine-AP), diaphorase (DIA, 1.8.1.4), glutamate-oxaloacetate transamininase (GOT , 2.6.1.1 (= aspartate aminotransferase, AAT)), isocitrate dehydrogenase (IDH, 1.1.1.42), malate dehydrogenase (MDH, 1.1.1.37), peroxidase (PER, 1.11.1.7), 6phosphogluconate dehydrogenase (GPGDH, 1.1.1.44), phosphoglucose isomerase (PGI, 5.3.1.9), phosphoglucomutase (PGM, 5.4.2.2), shikimate dehydrogenase (SKDH, 1.1.1.25). Genotypes were scored at 13 polymorphic gene loci: AP-A, DIA-A, GOT-B,C, IDH-A, MDH-B,C, PER-B, 6PGD-A,B, PGI-B, PGM-A, SKDH-A.

\section{Measurement of genetic variation}

Intrapopulational variation was measured by means of the observed and the conditional heterozygosities $\left(H_{\mathrm{a}}, H_{\mathrm{C}}\right.$ ), (Gregorius et al, 1986), the number of alleles and of genotypes per locus, and the genic (allelic) diversities (Gregorius, 1987). Interpopulational variation was quantified by genetic distance (Gregorius, 1974) and population differentiation (Gregorius and Ro- berds, 1986); for a summary see Müller-Starck and Gregorius (1986).

\section{RESULTS AND DISCUSSION}

\section{Intrapopulational variation in Quercus robur and $Q$ petraea}

\section{Average degrees of heterozygosity}

Results are summarized in tables II and III; The conditional heterozygosities $\left(H_{c}\right)$ are given in addition to the observed heterozygosities $\left(H_{a}\right)$ because the latter values can be biased as a consequence of their dependency upon the underlying gene frequencies. For $H_{a}$, the given multilocus mean is arthmetic; for $H_{c}$ it is equal to the ratio of the summed $H_{\mathrm{a}}$ values to the summed maximum attainable heterozygosities.

The $H_{\mathrm{a}}$ values showed substantial variation among the gene loci. Loci reflecting 
Table II. Actual (observed) heterozygosities for 13 polymorphic gene loci of 5 samples of $Q$ robur (15 ) and of $Q$ petraea (6-10). Multipopulation samples are marked by asterisks.

\begin{tabular}{|c|c|c|c|c|c|c|c|c|c|c|}
\hline \multirow[t]{3}{*}{ Gene locus } & \multicolumn{10}{|c|}{ Actual heterozygosities $\left(\mathrm{H}_{a} \%\right)$ for population sample } \\
\hline & $1^{*}$ & $2^{*}$ & $3^{*}$ & 4 & 5 & $6^{*}$ & $7 *$ & 8 & 8 & 10 \\
\hline & \multicolumn{5}{|c|}{ Quercus robur } & \multicolumn{5}{|c|}{ Quercus petraea } \\
\hline AP-A & 41.3 & 45.1 & 51.5 & 42.5 & 36.5 & 46.7 & 44.4 & 28.5 & 54.6 & 47.6 \\
\hline DIA-A & 48.6 & 47.1 & 57.4 & 50.0 & 59.4 & 44.9 & 63.9 & 60.1 & 56.4 & 41.7 \\
\hline GOT-B & 7.7 & 2.5 & 4.0 & 2.5 & 1.0 & 7.8 & 8.3 & 10.0 & 14.9 & 0 \\
\hline GOT-C & 12.5 & 18.6 & 27.0 & 11.7 & 31.2 & 22.7 & 30.6 & 14.0 & 21.8 & 32.1 \\
\hline IDH-A & 39.9 & 39.2 & 48.5 & 31.7 & 49.0 & 35.6 & 40.3 & 44.3 & 20.7 & 26.2 \\
\hline MDH-B & 0.5 & 1.0 & 0 & 0 & 0 & 0 & 0 & 0 & 0 & 2.4 \\
\hline $\mathrm{MDH}-\mathrm{C}$ & 4.3 & 4.4 & 0 & 10.8 & 8.3 & 0 & 1.4 & 0 & 1.7 & 0 \\
\hline PER-B & 50.9 & 54.9 & 25.5 & 32.5 & 46.9 & 47.6 & 41.7 & 48.7 & 60.9 & 60.7 \\
\hline 6PGD-A & 5.3 & 5.9 & 1.0 & 2.5 & 5.2 & 5.6 & 5.6 & 14.5 & 0 & 3.6 \\
\hline 6PGD-B & 7.2 & 13.2 & 6.9 & 5.8 & 6.2 & 5.1 & 2.8 & 13.6 & 1.7 & 2.4 \\
\hline PGI-B & 14.9 & 10.3 & 12.7 & 12.5 & 26.0 & 9.8 & 22.2 & 21.1 & 3.4 & 8.3 \\
\hline PGM-A & 31.7 & 34.3 & 39.2 & 35.8 & 39.6 & 30.6 & 37.5 & 38.6 & 23.0 & 17.9 \\
\hline SKDH-A & 0 & 1.0 & 7.4 & 4.2 & 8.3 & 6.5 & 6.9 & 22.4 & 32.2 & 2.4 \\
\hline \multirow[t]{2}{*}{ Mean } & 20.4 & 21.3 & 21.6 & 18.7 & 24.4 & 20.2 & & 24.3 & 22.4 & 18.9 \\
\hline & \multicolumn{5}{|c|}{$\begin{array}{c}\text { Quercus robur } \\
21.3\end{array}$} & \multicolumn{5}{|c|}{$\begin{array}{c}\text { Quercus petraea } \\
21.9\end{array}$} \\
\hline
\end{tabular}

Table III. Conditional heterozygosities in correspondence to table II. Asterisks indicate multipopulation samples.

\begin{tabular}{|c|c|c|c|c|c|c|c|c|c|c|}
\hline \multirow[t]{3}{*}{ Gene locus } & \multicolumn{10}{|c|}{ Conditional heterozygosities $\left(\mathrm{H}_{c} \%\right)$ for population sample } \\
\hline & $1^{*}$ & $2^{*}$ & 3 * & 4 & 5 & $6^{*}$ & 7 & 8 & 9 & 10 \\
\hline & \multicolumn{5}{|c|}{ Quercus robur } & \multicolumn{5}{|c|}{ Quercus petraea } \\
\hline AP-A & 51.2 & 45.1 & 51.5 & 53.1 & 36.5 & 47.6 & 44.4 & 38.9 & 60.9 & 47.6 \\
\hline DIA-A & 65.2 & 58.3 & 87.5 & 56.6 & 71.2 & 75.8 & 63.9 & 78.3 & 64.5 & 94.6 \\
\hline GOT-B & 88.9 & 100.0 & 100.0 & 100.0 & 100.0 & 81.0 & 60.0 & 92.0 & 86.6 & 0 \\
\hline GOT-C & 86.7 & 70.4 & 74.6 & 100.0 & 76.9 & 75.4 & 44.0 & 29.3 & 97.3 & 69.2 \\
\hline IDH-A & 73.4 & 60.5 & 79.2 & 46.3 & 68.1 & 73.3 & 74.4 & 78.3 & 78.4 & 78.6 \\
\hline $\mathrm{MDH}-\mathrm{B}$ & 50.0 & 100.0 & 0 & 0 & 0 & 0 & 0 & 0 & 100.0 & \\
\hline $\mathrm{MDH}-\mathrm{C}$ & 97.8 & 59.5 & 0 & 100.0 & 57.1 & 0 & 100.0 & 0 & 100.0 & 0 \\
\hline PER-B & 50.9 & 54.9 & 29.4 & 40.2 & 54.9 & 47.6 & 45.5 & 59.7 & 62.3 & 60.7 \\
\hline 6PGD-A & 57.6 & 50.0 & 100.0 & 100.0 & 100.0 & 54.9 & 66.7 & 55.9 & 0 & 100.0 \\
\hline 6PGD-B & 88.2 & 69.2 & 101.4 & 100.0 & 100.0 & 54.6 & 100.0 & 46.9 & 15.8 & 100.0 \\
\hline PGI-B & 93.9 & 59.9 & 59.1 & 65.2 & 64.1 & 60.0 & 76.2 & 69.9 & 25.0 & 77.8 \\
\hline PGM-A & 38.4 & 37.0 & 39.8 & 36.8 & 42.2 & 31.4 & 43.5 & 46.1 & 26.1 & 30.0 \\
\hline SKDH-A & 0 & 25.0 & 100.0 & 100.0 & 80.0 & 70.0 & 55.6 & 43.6 & 87.5 & 100.0 \\
\hline \multirow[t]{2}{*}{ Mean } & 58.3 & 53.0 & 60.6 & 53.8 & 57.4 & 54.2 & 53.6 & 55.7 & 59.2 & 60.6 \\
\hline & \multicolumn{5}{|c|}{$\begin{array}{c}\text { Quercus robur } \\
56.6\end{array}$} & \multicolumn{5}{|c|}{$\begin{array}{c}\text { Quercus petraea } \\
56.7\end{array}$} \\
\hline
\end{tabular}


large heterozygosities were: AP-A, DIA-A, IDH-A, PER-B and PGM-A. Variation among the samples was particularly indicated by the gene loci PER-B and SKDHA. The mean $H_{a}$ value for the 2 oak species were nearly the same: $21.3 \%$ for $Q$ robur and $21.9 \%$ for $Q$ petraea. The average values of the multipopulation samples were slightly smaller than the species mean (21.1\% for $Q$ robur) or identical to it.

Deviating trends in the $H_{c}$ values (see table III) as compared to the $H_{a}$ values were a consequence of differences in the gene frequencies among samples and among loci within samples. For instance, AP-A, PER-A and PGM-A reflected great $H_{\mathrm{a}}$ values but small $H_{\mathrm{c}}$ values. This difference leads the $H_{a}$ values to appear large but to be small in reality, if the potential to form heterozygotes is taken into consideration. The opposite trend was revealed, for instance, by the loci GOT-B and 6PGDHB: large $H_{c}$ values demonstrated that the extraordinarily small $H_{a}$ values could not have been much larger due the underlying allele frenquecies ( 1 frequent and a few very rare alleles). Loci AP-A, DIA-A, IDH$A, P E R-B$ and PGM-A have 2 or 3 alleles. The variation with respect to $M D H-B$ and $\mathrm{MDH}-\mathrm{C}$ was primarily a consequence of gene frenquency distributions close to fixa- tion in most of the samples. The multilocus mean values showed little deviation among the samples. The overall mean values of the species were nearly identical $(56.6 \%$ and $56.7 \%$, respectively).

Generally, pronounced species-specific effects were lacking and the sampling mode (multipopulation samples vs locally separated ones) did not seem to affect the heterozygosities considerably. The observed heterozygosities did not deviate much from those reported for other deciduous tree species, such as Fagus sylcatica: corresponding values (2-yr old plants from 5 multipopulation samples genotyped at 12 gene loci) were; $H_{\mathrm{a}}=22.2 \%$ and $H_{\mathrm{c}}=$ $52.4 \%$ (Müller-Starck and Ziehe, 1991).

\section{Genetic multiplicity}

Genetic multiplicity in terms of average number of alleles or genotypes per locus is summarized in table IV. There is no allele which occurs in all samples of one species but not in any sample of the other species. Alleles which are represented in some of the samples of only one species are so rare $(\approx 1 \%)$ that sample size may account for the non-representation in the other species.

Table IV. Averge number of alleles and of genotypes per locus $\left(A_{L}, G_{L}\right)$ for 13 gene loci and 10 oak samples. Asterisks indicate multipopulation samples.

\begin{tabular}{|c|c|c|c|c|c|c|c|c|c|c|}
\hline \multirow[t]{2}{*}{ Locus } & \multicolumn{5}{|c|}{ Quercus robur } & \multicolumn{5}{|c|}{ Quercus petraea } \\
\hline & $1^{*}$ & 2 * & $3 *$ & 4 & 5 & $6^{*}$ & $7^{*}$ & 8 & 9 & 10 \\
\hline $\begin{array}{l}A_{L} \\
\text { Mean }\end{array}$ & 3.4 & 3.5 & $\begin{array}{l}3.4 \\
3.2\end{array}$ & 2.9 & 2.9 & 3.2 & 3.2 & $\begin{array}{l}3.5 \\
3.1\end{array}$ & 2.9 & 2.7 \\
\hline $\begin{array}{l}G_{L} \\
\text { Mean }\end{array}$ & 5.5 & 6.1 & $\begin{array}{l}5.5 \\
5.1\end{array}$ & 4.0 & 4.6 & 5.6 & 4.9 & $\begin{array}{l}6.9 \\
5.4\end{array}$ & 5.1 & 4.4 \\
\hline
\end{tabular}


The largest mean numbers of alleles were revealed by the gene loci PER-B (5.3) and AP-A (4.7), the smallest ones by $\mathrm{MDH}-\mathrm{B}$ (1.5) and MDH-C (1.8). The multilocus means of the samples from multipopulations compared to single populations (3.4 vs 2.9 for $Q$ robur, 3.3 vs 2.8 for $Q$ petraea. The overall means of both species are nearly indentical (3.2 and 3.1 alleles locus).

The mean number of genotypes per locus varied more among the samples than the gene number did. This finding is not only a consequence of the sample sizes: the sizes of samples 5,7 and 10 are extraordinarily small (between 72 and 96 individuals) (see table I) but these samples did not reveal the smallest number of genotypes per locus. In contrast to the mean number of alleles per locus, the corresponding values for genotypes were smaller in $Q$ robur than in $Q$ petraea, ie, 5.1 vs 5.4 genotypes per locus (for $Q$ robur, this is equivalent to $76 \%$ of the maximum attainable mean number of genotypes; for $Q$ petraea to $85 \%$ ). For the time being it is suggested that characteristics of the reproductive system of the respective parental populations may contribute to these phenomena.

\section{Genic (allelic) diversity}

The multilocus values (see table $V$ ) were calculated as harmonic means. The hypothetical gametic multilocus diversity (HGMD)

Table V. Genic (allelic) diversity and hypothetical gametic multilocus diversity (HGMD) in 10 oak populations. Asterisks indicate multipopulation samples.

\begin{tabular}{|c|c|c|c|c|c|c|c|c|c|c|}
\hline \multirow[t]{2}{*}{ Gene locus } & \multicolumn{10}{|c|}{ Genic (allelic) diversity in 10 samples } \\
\hline & \multicolumn{5}{|c|}{ Quercus robur } & \multicolumn{5}{|c|}{ Quercus petraea } \\
\hline AP-A & 2.3 & 3.0 & 2.8 & 2.4 & 2.7 & 2.7 & 2.8 & 2.1 & 2.5 & 2.4 \\
\hline DIA-A & 2.0 & 2.0 & 1.9 & 2.2 & 2.1 & 1.8 & 2.4 & 2.2 & 2.4 & 1.5 \\
\hline GOT-B & 1.1 & 1.0 & 1.0 & 1.0 & 1.0 & 1.1 & 1.2 & 1.1 & 1.2 & 1.0 \\
\hline GOT-C & 1.2 & 1.3 & 1.5 & 1.1 & 1.5 & 1.4 & 2.1 & 1.7 & 1.3 & 1.6 \\
\hline IDH-A & 1.7 & 1.8 & 1.7 & 2.0 & 2.0 & 1.6 & 1.7 & 1.7 & 1.3 & 1.4 \\
\hline MDH-B & 1.0 & 1.0 & 1.0 & 1.0 & 1.0 & 1.0 & 1.0 & 1.0 & 1.0 & 1.0 \\
\hline MDH-C & 1.0 & 1.1 & 1.0 & 1.1 & 1.2 & 1.0 & 1.0 & 1.0 & 1.0 & 1.0 \\
\hline PER-B & 3.3 & 3.6 & 2.6 & 2.7 & 2.5 & 3.8 & 2.5 & 2.5 & 3.1 & 3.5 \\
\hline 6PGD-A & 1.1 & 1.1 & 1.0 & 1.0 & 1.1 & 1.1 & 1.1 & 1.3 & 1.0 & 1.0 \\
\hline 6PGD-B & 1.1 & 1.2 & 1.1 & 1.1 & 1.1 & 1.1 & 1.0 & 1.3 & 1.1 & 1.0 \\
\hline PGI-B & 1.2 & 1.2 & 1.2 & 1.2 & 1.5 & 1.2 & 1.3 & 1.4 & 1.1 & 1.1 \\
\hline PGM-A & 2.0 & 2.1 & 2.1 & 2.1 & 2.1 & 2.2 & 2.1 & 2.1 & 1.9 & 1.8 \\
\hline SKDH-A & 1.0 & 1.0 & 1.1 & 1.0 & 1.1 & 1.1 & 1.1 & 1.7 & 1.4 & 1.0 \\
\hline \multirow[t]{2}{*}{ Mean } & 1.3 & 1.4 & 1.4 & 1.3 & 1.4 & 1.4 & 1.4 & 1.5 & 1.4 & 1.3 \\
\hline & \multicolumn{5}{|c|}{$\begin{array}{c}\text { Quercus robur } \\
1.4\end{array}$} & \multicolumn{5}{|c|}{$\begin{array}{c}\text { Quercus petraea } \\
1.4\end{array}$} \\
\hline HGMD & \multicolumn{5}{|c|}{$\begin{array}{c}\text { Quercus robur } \\
137.2\end{array}$} & \multicolumn{5}{|c|}{$\begin{array}{l}\text { Quercus petraea } \\
176.5\end{array}$} \\
\hline
\end{tabular}


is equal to the number of genetically different gametic types which hypothetically can be produced by individuals of each sample on the basis of their 13-locus genotypes

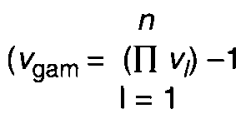

where $v_{l}$ is the diversity at locus $)$ (Gregorius et al, 1986). This measure quantifies the potential for creating genetic variation in the next generation and is therefore an important determinant of the adaptability of forest tree populations.

In most cases, the single locus genic diversities reflected trends similar to those observed in the genic multiplicities (eg, largest values for PER-B and AP-A). This was not true in cases of deviating distributions of allele frenquencies; for instance, the locus DIA-A reflected on the average smaller numbers of alleles but larger genic diversities than the GOT-C locus (DIA-A: 3.4 vs 2.1; GOT-C: 4.0 vs 1.5). The reason for this difference is the greater deviation of the allele frequencies from the state of eveness in the case of GOT-C compared to that of DIA-A.

The variation among the multilocus means of the samples was smaller than that among the mean number of alleles per locus (see table IV). In both species, there was not more deviation between the values from multipopulation samples and those from single populations.

The hypothetical gametic multilocus diversities revealed a large variation among the samples. The sample size did not seem to affect these values substantially, because 2 of the smallest samples $(5,7)$ show quite large multilocus values. In the case of Quercus robur, the values of the single population samples did not deviate much from those of the mixed samples (on the average 136.9 vs 137.4), but are con- siderably smaller in the case of Quercus petraea (164.9 vs 193.9).

\section{Interpopulational variation in Quercus robur and $Q$ petraea}

\section{Genetic distances}

In table VI, results are given for 2 out of 13 loci: AP-A represents those loci which reveal in both species, at least for some pairs of samples, considerably large genic (allelic) distances; SKDH-A, showed on the average, large values for Quercus petraea but remarkably small values for $Q$ robur. In this sense, SKDH-A reveals greater deviations among the 2 species than any other locus.

From the results of a statistical analysis between samples (log likelihood ratio test of homogeneity in contingency tables), it can be stated that genic distance values greater than 0.1 will reveal significant deviations in most cases (at least at a significance level of 0.05). Genic distances larger than 0.2 can be expected to indicate substantial interpopulational genetic variation. For many pairs of samples, these values are exceeded, eg, in case of populations 8 and 9 (APA). Each of these populations can be discriminated easily from the other populations but not from each other. The similarity between populations 8 and 9 is a surprising observation because these 2 samples originate from single populations and should relect more specific genetic information than mixed samples. As can be seen from the same table, this trend was not confirmed by SKDH-A. The highly specific monitoring effect of adaptive loci may account for this phenomenon.

\section{Genetic differentiation}

Genetic differentiation was quantified by means of the genetic distances between 
Table VI. Genic (allelic) distances among 10 oak populations (Popul) for 2 gene loci (AP-A in the upper right diagonal half, SKDH-A in the lower diagonal half). Asterisks indicate multipopulation samples.

\begin{tabular}{|c|c|c|c|c|c|c|c|c|c|c|}
\hline \multirow[t]{3}{*}{ Popul } & \multicolumn{10}{|c|}{ Genic distance between pairs of populations } \\
\hline & 1 * & $2 *$ & $3^{*}$ & 4 & 5 & $6 *$ & $7^{*}$ & 8 & 9 & 10 \\
\hline & \multicolumn{5}{|c|}{ Quercus robur } & \multicolumn{5}{|c|}{ Quercus petraea } \\
\hline 1 & - & 0.14 & 0.12 & 0.03 & 0.18 & 0.09 & 0.16 & 0.46 & 0.39 & 0.29 \\
\hline 2 & 0.02 & - & 0.05 & 0.15 & 0.12 & 0.08 & 0.11 & 0.37 & 0.31 & 0.24 \\
\hline 3 & 0.04 & 0.03 & - & 0.12 & 0.10 & 0.03 & 0.08 & 0.36 & 0.30 & 0.21 \\
\hline 4 & 0.02 & 0.01 & 0.03 & - & 0.21 & 0.11 & 0.19 & 0.47 & 0.41 & 0.32 \\
\hline 5 & 0.05 & 0.05 & 0.02 & 0.04 & - & 0.10 & 0.04 & 0.29 & 0.23 & 0.13 \\
\hline 6 & 0.05 & 0.03 & 0.03 & 0.03 & 0.04 & - & 0.08 & 0.37 & 0.31 & 0.21 \\
\hline 7 & 0.06 & 0.05 & 0.03 & 0.04 & 0.01 & 0.05 & - & 0.32 & 0.26 & 0.19 \\
\hline 8 & 0.26 & 0.24 & 0.22 & 0.24 & 0.20 & 0.23 & 0.19 & - & 0.08 & 0.18 \\
\hline 9 & 0.18 & 0.16 & 0.18 & 0.17 & 0.17 & 0.16 & 0.16 & 0.22 & - & 0.15 \\
\hline 10 & 0.01 & 0.01 & 0.03 & 0.01 & 0.05 & 0.03 & 0.05 & 0.25 & 0.17 & - \\
\hline
\end{tabular}

one sample an the remaining ones which were combined in order to form the respective complement population. In this way genetic variation was measured as a whole and not only in pairs.

Figures 1 and 2 illustrate genetic differentiation for 5 out of 13 gene loci (for a summary of numerical multilocus values, see Müller-Starck and Ziehe, 1991). For each species, the graphs refer to the allele frequencies. In each graph, the radius of the dotted line is equal to the average level of differentiation at that particular locus. The given scale measures the average proportion of genes by which any sample differs from the remainder. For each graph, the radii of the sample-specific sectors are equal to the proportion of genes by which one sample differs from the pooled remainder (the angles of the sectors correspond to the sample size). The more the sector radii approach the center, the more representative of the remainder is the genetic information of this sample, and is equivalent to reduction of sample- specific information. In the combined presentation (see graph 'gene pool'), locispecific effects can be compensated.

The single locus graph show that the average level of differentiation varied considerably among the loci and among the species. For both species, a large level of differentiation was found for instance, for PER-B. Deviations between the 2 species were particularly evident in the case of SKDH-A and to a certain extent also those of AP-A and GOT-C. The gene pool graph indicates greater differentiation among the samples of Quercus petraea than among those of $Q$ robur. Within the first species, samples 4 and 5 were differentiated above average, although the differences among the samples were small. In the case of Quercus petraea, all samples except no 6 were differentiated above average. The samples which originated from seed collections in single populations (no 4 and 5 , and 8,9 and 10) tended to be more differentiated than the remaining samples which descend from population mixtures. This ob- 

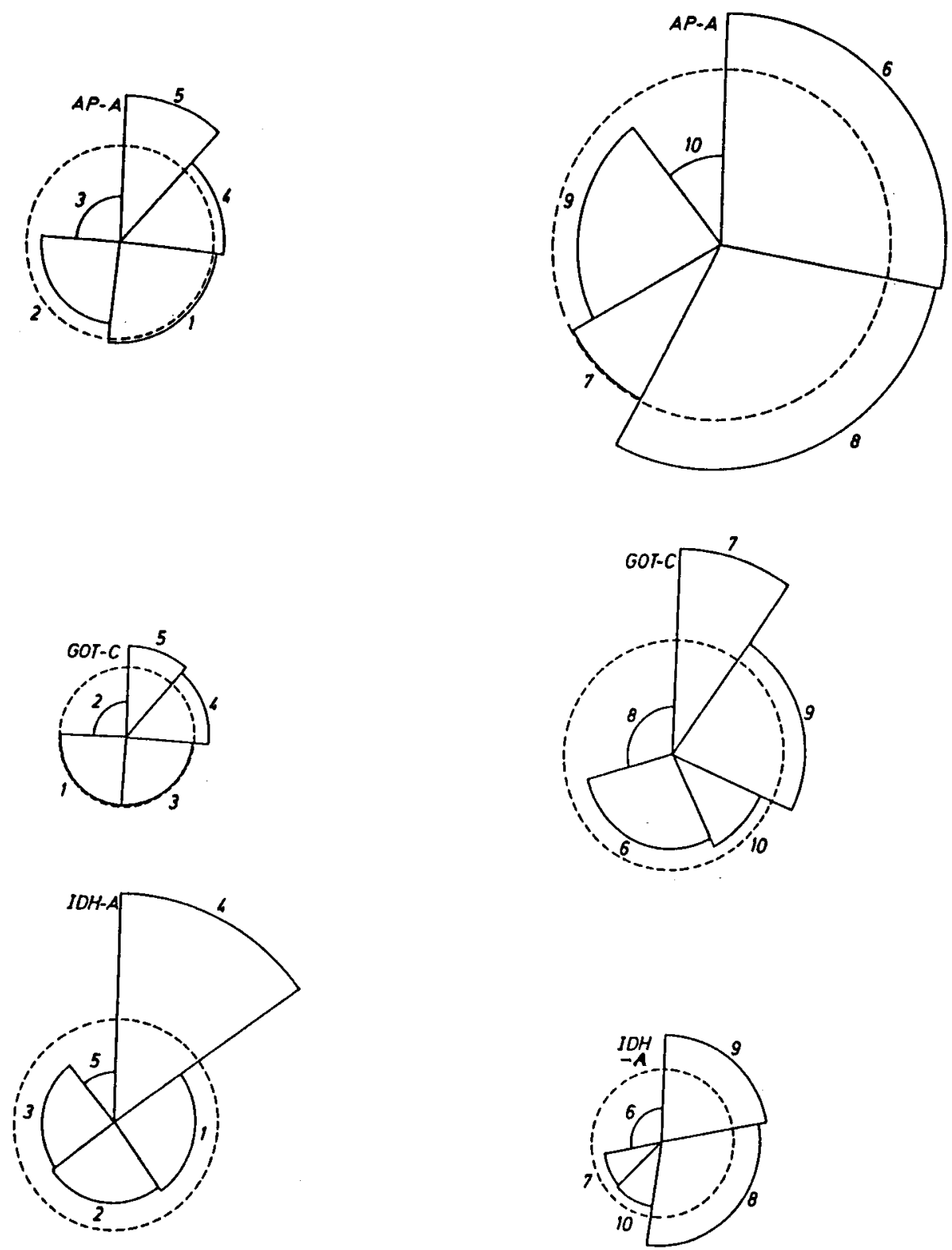

Quercus robur (samples 1-5)

Quercus petraea (samples 6-10)

Fig 1. Genetic differentiation among oak samples for AP-A, GOT-C, IDH-A. 

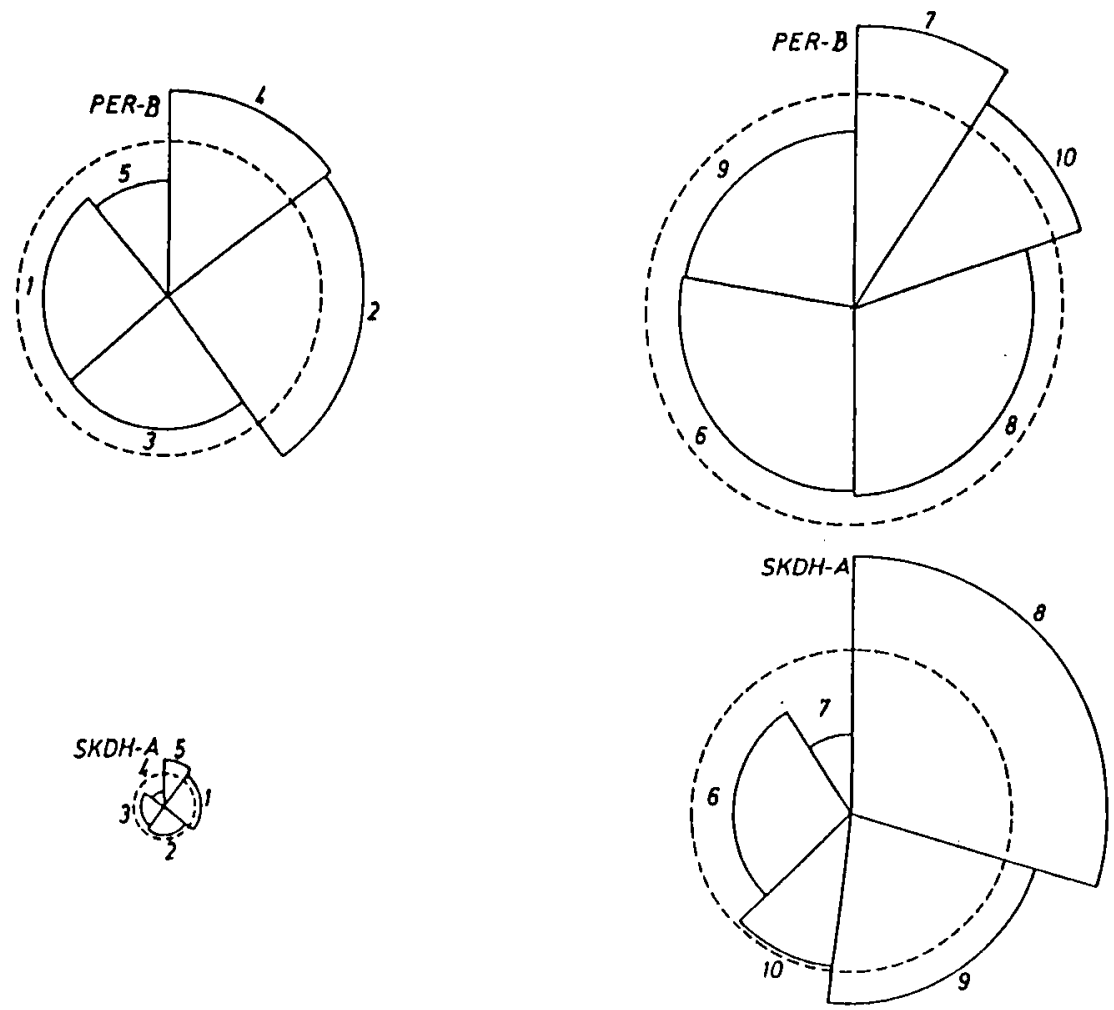

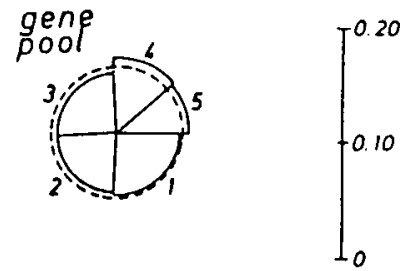

Quercus robur (samples 1-5)

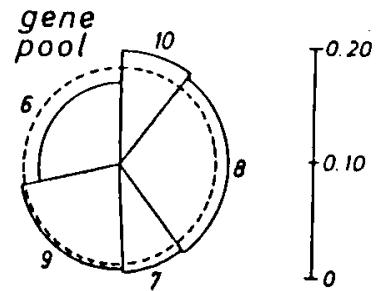

Quercus petraea (samples 6-10)

Fig 2. Genetic differentiation among oak samples for PER-B, SKDH-A, and the gene pool with respect to 13 loci. 
servation means that single population samples share a smaller proportion of the entire genetic information than the mixed ones.

\section{CONCLUSIONS}

Enzyme gene marker reveals a substantial genetic similarity between Quercus robur and $Q$ petraea. None of the genes was represented exclusively in only one of the species. Within each species, heterozygosities appear to be smaller than in several other tree species (for comparison of parameters and references, see MüllerStarck, 1991). Because information about heterozygosities in adult stands is still lacking, it cannot be excluded that relatively low heterozygosities might characterize juvenile Quercus populations but not the succeeding life stages. The genetic multiplicity was very large in all samples investigated including single-population samples. This finding concurs with results of a recent study in 32 European populations of Quercus petraea (Kremer et al, 1991). Great intrapopulational variation could indicate a successful strategy of adaptation and survival of species which are extremely long-lived and exposed to extraordinarily heterogeneous environments. Relatively small genetic diversities indicate minor polymorphisms, ie, a constellation with 1 predominant and a few rare alleles. The genetic distances between pairs of samples indicate remarkable differences in many cases. These values tend to be higher than those of Kremer et al (1991). The illustrated genetic differentiation reveals that multipopulation samples tend to share a larger proportion of the entire gene pool than each of the single-population samples. Gene loci reveal very different trends because each of the adaptive gene loci may be subject to different selective forces and thus monitor genetic similarities or dis- similarities among populations in a very specific way.

The results presented herein suggest that forest tree breeding and silviculture of Quercus robur and $Q$ petraea need to take into account large genetic multiplicities. Such genetic heterogeneity seems to correspond to the tremendous environmental heterogeneity to which long-lived oak populations are exposed. Particularly in oak species, it appears that large genetic variation should be incorporated in productive populations in order to maintain the potential of these populations to adapt to and to survive in complex environmental situations.

\section{ACKNOWLEDGMENTS}

The technical assistance of $G$ Dinkel is greatly appreciated. This study was financially supported by the Commission of the European Communities, GD XII, Brussels, Belgium.

\section{REFERENCES}

Anonymous (1972) Erste Verordnung zur Durchführung des Gesetzes über forstliches Saat-und Pflanzgut (1 FSaat V). Bundesgesetzblatt I, 92, 1561-1586

Gregorius HR (1974) Genetischer Abstand zwischen Populationen. 1. Zur Konzeption der genetischen Abstandsmessung. Silvae Genet $23,22-27$

Gregorius HR (1978) The concept of genetic diversity and its formal relationship to heterozygosity and genetic distance. Math Biosci 41 , 253-271

Gregorius HR, Roberds JH (1986) Measurement of genetical differentiation among subpopulations. Theor App/ Genet 71, 826-834

Gregorius HR, Krauhausen J, Müller-Starck G (1986) Spatial and temporal genetic differentiation among the seed in a stand of Fagus sylvatica L. Heredity 57, 255-262

Kremer A, Petit R, Zanetto A, Fougere V, Ducousso A, Wagner D, Chauvin C (1991) Nu- 
clear and organelle gene diversity in Quercus robur and Quercus petraea. In: Genetic Variation in European Populations of Forest Trees (Müller-Starck G, Ziehe M, eds) Sauerländer-Verlag, Frankfurt-Am-Main, 141166

Müller-Starck G (1991) Survey of genetic variation inferred from enzyme gene markers. In: Genetic Variation of Forest Tree Populations in Europe (Müller-Starck G, Ziehe M, eds) Sauerländer-Verlag, Frankfurt-am-Main, 2037

Müller-Starck G, Gregorius HR (1986) Monitoring genetic variation in forest tree popula- tions. In: Proc 19th IUFRO World Congr. Ljubljana, Yugoslavia, 1986, div 2, vol II, 589599

Müller-Starck G, Hattemer HH (1990) Genetics and Breeding of Oaks. Final Report, MA 1B0012-D, CEC, DG XII, Brussels, Belgium, $22 \mathrm{pp}$

Müller-Starck G, Ziehe M (1991) Genetic variation in populations of Fagus sylvatica, Quercus petraea, and $Q$ robur in Germany. In: Genetic Variation of Forest Tree Populations in Europe (Müller-Starck G, Ziehe $M$, eds) Sauerländer-Verlag, Frankfurt-am-Main, 125140 